Inga Kacevska, Dr. iur., Associate Professor

University of Latvia, Latvia

\title{
NE BIS IN IDEM PRINCIPLE IN ARBITRATION - LATVIAN PERSPECTIVE
}

\begin{abstract}
Summary
On the basis of one case where an arbitration institution twice has rendered two arbitral awards in the same claim between the same parties and with the same subject matter in Latvia, this article examines the differences between the notion ne bis in idem and res judicata of arbitral award in international and national scenery. Unfortunately, Arbitration Law of Latvia is so incomplete that both the practice and commentators suggest that re-arbitrating the same claim is a standard. Moreover, as Latvia does not follow Model Law, there is no set aside proceedings available in Latvia.
\end{abstract}

Keywords: $n$ e bis in idem, arbitral award, set aside, res judicata

\section{Introduction: $\mathrm{Ne}$ Bis In Idem in international arbitral scenery}

The ne bis in idem (not twice for the same thing) principle is a corollary of res judicata (a thing adjudicated) principle. Once a case has been decided by a valid and final judgment (award), the same issue may not be disputed again between the same parties, so long as that judgment stands (negative effect of res judicata). ${ }^{1}$ The latter doctrine is a clear example of a general principle of law recognized by civilised nations and reflects a permanent wisdom regardless of times. ${ }^{2}$

If ne bis in idem is not explicitly mentioned in the international arbitration sources, such as New York Convention on Recognition and Enforcement of Foreign Arbitral Awards (New York Convention) ${ }^{3}$ or European Convention on International Commercial Arbitration (European Convention) ${ }^{4}$, res judicata concept is obviously incorporated in Article III of the New York Convention, stating:

Each Contracting State shall recognize arbitral awards as binding and enforce them in accordance with the rules of procedure of the territory where the award is relied upon, under the conditions laid down in the following articles.

1 Hanotiau B. Complex Arbitration: Multiparty, Multicontract, Multi-Issue and Class Actions. Kluwer Law International, 2006, p. 240.

2 Barnett P. Res Judicata, Estoppel, and Foreign Judgments. Oxford University Press, 2009, p. 8

3 United Nations Convention on the Recognition and Enforcement of Foreign Arbitral Awards. 330 UNTS 38, 1968.

4 European Convention on International Commercial Arbitration. 484 U.N.T.S. 364, 1961. 
The drafters of the New York Convention intended to eliminate wasteful, duplicative litigation following arbitration. ${ }^{5}$ Therefore this wording leads us to determine that also arbitral awards have preclusive effect and the case has been concluded and reviewed on merits. In other words, internationally arbitral awards, too, can amount to "judicial decisions" for res judicata purposes. ${ }^{6}$ Moreover, generally an award made in a locally-seated arbitration does not require confirmation in order to have preclusive effects; the award will have preclusive effects from the moment it is made. In the case of an award made in a foreign-seated arbitration, most jurisdictions require that the award first be recognized, before it will have preclusive effects in local courts. ${ }^{7}$

Do Latvian law and practice reflect this wisdom?

The purpose of this article is to discuss whether a legal construct ne bis in idem exists in Latvian arbitration environment. The article also will show how shortcomings in the national legislation can lead to the breach of one of the main legal principles. The article does not discuss historical development or any other versions of the principle. The author will mostly use inductive reasoning to draw a general conclusion from one specific case.

\section{Facts and holding: the Latvian case ${ }^{8}$}

On 20 May 2013, natural persons A and B (Russia) as borrowers and the bank (Latvia) as a creditor concluded the Credit Agreement. This Agreement provided that all disputes shall be settled upon choice of a claimant either by the court of the Republic of Latvia or by the Court of Arbitration of the Association of Latvian Commercial Banks.

As borrowers did not fulfil the Credit Agreement, the Bank submitted the claim to the Court of Arbitration of the Association of Latvian Commercial Banks that rendered award against A and B on 3 August 2015. The bank sought recognition and enforcement of the award in the Russian Federation but the Russian court refused to recognize and enforce the award referring to its public policy, i.e., the Court of Arbitration of the Association of Latvian Commercial Banks did not properly inform both respondents about the arbitration and that arbitrators exceeded its mandate.

David V. Rivkin. Chapter 10. The Impact of Parallel and Successive Proceedings on the Enforcement of Arbitral Awards. In: Bernardo Cremades Sanz Pastor and Julian David Mathew Lew (eds.), Parallel State and Arbitral Procedures in International Arbitration, Dossiers of the ICC Institute of World Business Law, Vol. 3, Kluwer Law International; International Chamber of Commerce, 2005, p. 272.

6 Barnett p. 13, also Hanotiau, 2006, p. 245; International Law Association Resolution No. 1/2006 Recommendations on Lis Pendens and Res Judicata and Arbitration, 4-8 June 2006:

An arbitral award has conclusive and preclusive effects in further arbitral proceedings if: 3.1 it has become final and binding in the country of origin and there is no impediment to recognition in the country of the place of the subsequent arbitration.

7 Born G. International Commercial Arbitration, Vol. III, Wolters Kluwer, 2014, p. 2909.

8 Judgment of Riga District Court of 1 November 2017 in the civil case No C30748516. Available at: https://manas.tiesas.lv/eTiesasMvc/nolemumi/pdf/347096.pdf [last viewed October 21, 2019]. 
However, the bank repeatedly submitted the same claim against both persons in the Court of Arbitration of the Association of Latvian Commercial Banks. Persons A and B were informed properly about the arbitral proceedings, and thus the procedural discrepancies of the first proceedings were "cured". On 23 May 2016, the Court of Arbitration rendered the second award against persons A and B in the same case.

On 20 September 2016, the court of the Russian Federation recognized and enforced the latter award in accordance with New York Convention.

Right before recognition, on 16 September 2016 Persons A and B submitted the claim requesting to acknowledge the arbitration clause invalid in the court of the Republic of Latvia. Persons' A and B, inter alia, considered that the arbitration clause was executed and it became invalid after rendering the first award. The court of the Republic of Latvia denied the claim on the following grounds. Firstly, the court of the Russian Federation recognized the second arbitral award thus there were no reasons to acknowledge the arbitration agreement inoperative and executed. Secondly, the bank had the right to initiate the second arbitration against debtors in accordance with Article 537 of the Civil Procedure Law of the Republic of Latvia. ${ }^{9}$

The decision of the second instance court was appealed but the Supreme Court denied initiating the case in the cassation instance and it became into force on 14 March 2018.

This case may raise different legal questions: is an arbitration clause asymmetric? What is the scope of public policy? Are A and B consumers? What (if any) effect the Russian court decision shall have on the Latvian court's decision? Is arbitration agreement executed after award is made? Is this arbitration independent because one of the parties is the founder of the founding institution of the arbitral institution?

However, as indicated above, this article focuses on the issue whether the arbitration institution had a right to re-consider the case having the so-called "triple-identity criteria" (proceedings involving the same subject matter or relief, the same legal grounds and the same parties).

9 Civil Procedure Law. Available at: https://likumi.lv/ta/en/en/id/50500-civil-procedure-law [last viewed October 28, 2019]:

Section 537. Consequences of Refusal to Issue a Writ of Execution for Enforcement of a Judgment of a Permanent Arbitration Court

After a decision to refuse to issue a writ of execution for enforcement of a judgment of a permanent arbitration court has entered into effect:

1) the civil legal dispute may be resolved in a court according to the general procedures, if issue of the writ of execution for enforcement of a judgment of a permanent arbitration court has been refused on the basis of Section 536, Paragraph one, Clauses 1, 2, 3 and 7 of this Law;

2) the civil legal dispute may be repeatedly referred for resolution to an arbitration court, if the issue of the writ of execution for enforcement of a judgment of a permanent arbitration court has been refused on the basis of Section 536, Paragraph one, Clauses 4, 5 and 6 of this Law. 


\section{Legal framework and discussion}

\subsection{No set aside procedure in Latvia}

Initially, it shall be explained why it is possible in Latvia to render two arbitral awards in the same case and both arbitral awards stay in force. Latvia is not a UNCITRAL Model Law on International Commercial Arbitration (Model Law) ${ }^{10}$ country, even though "the Constitutional Court of the Republic of Latvia has also recognised that the Model Law is a standard of legal regulation used throughout the world." ${ }^{11}$ Latvia has chosen its own approach, thus, there is almost no court assistance in the arbitral proceeding as provided in UNICTRAL Model Law, and likewise there is no recourse against the award. Explicitly, in Latvia the interested party (like $\mathrm{A}$ and $\mathrm{B}$ in the case at hand) cannot request the court to set aside (annul, vacate) an arbitral award. ${ }^{12}$ It is striking that Latvia is party to the European Convention providing for the grounds to set aside the arbitral award, but there is no national procedural law to implement it in the practice. It has been proven that a legislative regime not providing for a possibility to challenge arbitral awards before ordinary jurisdiction courts violates parties' rights of access to a court under Article 6(1) of the European Convention of Human Rights. ${ }^{13}$

\subsection{Binding arbitral award under Latvian Arbitration Law?}

Article 51(2) of the Arbitration $\mathrm{Law}^{14}$ provides: "an award of an arbitration court shall come into effect on the day it is made" and Article 58 (1) states: "a judgment of an arbitration court is mandatory for the parties [..]". This differs from Article 35(1) of the Model Law that explicitly reads as follows: "an arbitral award, irrespective of the country in which it was made, shall be recognized as binding [..]". Such wording

10 UNCITRAL Model Law on International Commercial Arbitration (1985), with amendments as adopted in 2006. Legislation based on the Model Law has been adopted in 80 States in a total of 111 jurisdictions. See: https://uncitral.un.org/en/texts/arbitration/modellaw/commercial arbitration/status [last viewed October 21, 2019].

11 The Court continues:

the Model Law was elaborated with the aim of creating clear and comprehensive rules that would comprise fair and modern standards of international arbitration, which, as general legal principles, would be applicable in various legal and economic systems existing in the world.

Judgment of the Constitutional Court of 28 November 2014 in the case No. 2014-09-01, \$ 15.4. Available at: http://www.satv.tiesa.gov.lv/web/viewer.html?file=/wp-content/uploads/ 2014/03/2014-09-01_Spriedums_ENG.pdf\#search=2014-09-01 [last viewed May 2, 2019].

12 Born, 2014, p. 3390:

If an award is set aside in the place where it was made, then the award arguably ceases to have legal effect or existence (or becomes null), at least under the laws of the state where it was annulled, just as an appellate court decision vacates a trial court judgment.

13 Krūmiņš T. Arbitration and Human Rights: Lack of Setting-Aside Proceedings as a Violation of the ECHR. PhD Thesis at the University of Copenhagen, Faculty of Law, 2019, p. 381.

14 Arbitration Law. Available at: https://likumi.lv/ta/en/en/id/269189-arbitration-law [last viewed October 28, 2019]. 
also contrasts Article 16 (3) and (4) of the Law on Judicial Power: a judgment [of the court of the general jurisdiction] shall be binding on a court when examining other cases related to such matter and such a judgment shall have the force of law, shall be mandatory for all, and shall be treated with the same respect as is due law. ${ }^{15}$ If an arbitral award is binding only to the parties, the judgment of the court is mandatory for all. This means that the judgment of the court has a preclusive effect on arbitral proceedings, i.e., if the court (despite the arbitration clause) has rendered the judgment, that arbitral tribunal cannot review the same case again.

But what about the preclusive effect of arbitral award then? The above-cited ambiguity in the wording of the Arbitration Law leads to respective case law and commentaries. To be exact, the court of general jurisdiction has acknowledged that an arbitral award has no preliminary importance because the award is made by the arbitration, not the court. ${ }^{16}$ Similarly, the commentators have stated that the arbitral award has no prejudicial effect for the courts. ${ }^{17}$ Such conclusion is in contradiction with well-established international practice that the arbitral award has the same preclusive effects that national judgments. ${ }^{18}$ This clearly shows that both legislator and established practice did and do not trust national arbitral institutions, do not validate the arbitral awards thus facilitating duplication of proceedings and abuse of process.

However, in another case the Supreme Court concluded that when the court issues a writ of execution for compulsory enforcement of the award the court is under obligation to examine prejudicial award as far as it might affect another award in execution. ${ }^{19}$ This leads to conclusion that arbitral award might have res judicata effect towards another arbitral award. It is internationally agreed that, indeed, an arbitral award has conclusive and preclusive effects in the further arbitral proceedings. ${ }^{20}$

In general, it is questionable why in one case the court gives the preclusive effect to arbitral award (towards another arbitral award), but in another case (towards the court judgment) - does not.

Yet, applying this formula to the case at hand, one can determine that the first award made by the Court of Arbitration of the Association of Latvian Commercial Banks has res judicata effect and the claimant was barred from arbitrating the same

15 Law On Judicial Power. Available at: https://likumi.lv/ta/en/en/id/62847-on-judicial-power [last viewed October 28, 2019].

16 Judgment of Supreme Court of Latvia of 24 January 2013 in the civil case No. SKC-7/2013. Available at: http://www.at.gov.lv/downloadlawfile/3027 [last viewed October 28, 2019]. The court stated that the Article 96(2) of the Civil Procedure Law does not apply to arbitration awards:

Facts established pursuant to a judgment that has come into lawful force in one civil case need not be proved again in trying other civil cases involving the same parties.

17 Civilprocesa likuma komentāri. I dạ̦a (1.-28. nodaļa), Torgāns K. (scientific ed.), Tiesu namu aǵetūra, 2011, p. 268.

18 Born, 2014, p. 3741.

19 Judgment of Supreme Court of Latvia of 29 December 2014 in the civil case No. SPC-36/2014. Available at: http://www.at.gov.lv/downloadlawfile/2975 [last viewed October 28, 2019].

20 International Law Association Resolution No. 1/2006 "Recommendations on Lis Pendens and Res Judicata and Arbitration, 4-8 June 2006, para. 4. 
claim in the same arbitration. Nevertheless, A and B had no legal remedy to set aside either of the awards, as Latvian law does not provide for recourse of the arbitral award. Even more strikingly, the particular Court of Arbitrations in its rules provides that should the claimant repeatedly apply to the Court of Arbitration with the same claim because it has not received the writ of execution, the Chairman of the Arbitral Tribunal upon request of the claimant may release the claimant form payment of the arbitration expenses, provided that issue of the writ of execution was rejected due to breaches caused by the Court of Arbitration, and such breaches can be stated impartially. ${ }^{21}$ The Rules confirm that the same dispute can be re-arbitrated. ${ }^{22}$

The Constitutional Court also has stated: "[..] the control of arbitration courts is concentrated on the stage of issuance of the writ of execution..23 However, in the case at hand there was no need to turn to a court of general jurisdiction and request issuing a writ of execution because it needed recognition in another state. Even if there would be need for a writ of execution, the court had no direct legal powers to cure this procedural injustice and invalidate the arbitral award. This raises the next question: what would happen with both arbitral awards if in the case at hand the court were to acknowledge that the arbitration clause is not valid? Both arbitral awards would still be in force, as they cannot become automatically invalid. Therefore, the cited Article 537 (2) of the Civil Procedure Law is not logical. ${ }^{24}$ This problem was also recognized by the Constitutional Court, already in 2014, before the new Arbitration Law came into force, ${ }^{25}$ but again legislator failed to address it.

One more interesting aspect not discussed in the case at hand and in legal literature in Latvia is about the party's duty to raise the objections as concerns the prevention of duplicative claims. In general, arbitrators are not bound to observe res judicata effect of prior arbitral award ex officio, the preclusive effect of res judicata should be raised on a party's initiative as soon as possible in the proceedings. ${ }^{26}$ From the facts of the particular case we cannot establish whether A and B did or did not waive their rights to object. Still, in Latvia, despite such objections, even if

21 Article 38(5) of the Rules of the Court of Arbitration of the Association of Commercial Banks of Latvia, 2017. Available at: http://www.fstiesa.lv/en/court_of_arbitration/ [last viewed October $28,2019]$.

22 It shall be noted that this norm is cited in the referred judgment but clearly this norm should not have been applied to the case at hand, as this is not national case, where a writ of execution was refused.

23 Judgment of the Constitutional Court of the Republic of Latvia of 17 January 2005 in the case No. 2004-10-01 \$9.1.

24 See footnote 9.

25 "Law does not provide what happens with the award by an arbitration court if a court of general jurisdiction has refused to issue a writ of execution for its compulsory enforcement." Judgment of the Constitutional Court of 28 November 2014 in the case No. 2014-09-01, $\$ 22$.

26 Erk-Kubat N. Parallel Proceedings in International Arbitration: A Comparative European Perspective. Kluwer Law International, 2014, p. 234. 
the arbitral tribunal continues with the review of the second case, again there are no legal remedies to challenge such decision of arbitrators. ${ }^{27}$

In earlier judgment, the Constitutional Court has stressed: "in accordance with the general principle, the state is not responsible for violations of the fundamental rights in arbitration court", nevertheless, it could be liable for the incomplete legislation that violates international law, human rights and rights to due process. Moreover, the court of general jurisdiction shall interpret an incomplete law and fill the legal gaps and apply general legal principles of law if it can determine injustice. ${ }^{28}$

\section{Conclusions}

- It is internationally accepted that the facts established in one judgment or arbitral award that has come into lawful force (res judicata) shall not be re-litigated or rearbitrated (ne bis in idem), otherwise this results in abuse of process, fairness and economy of justice.

- Due to incomplete and outdated Arbitration Law in Latvia, the principle of ne bis in idem has clearly been violated. The cases have been re-arbitrated several times. This questions the creditability of the arbitration and legal system in general. Therefore, Latvia is not an internationally approved seat of arbitration and it is not endorsed as a forum of modern, clear and transparent rules.

- The Arbitration Law shall be harmonized with UNICTRAL Model Law, and there is a particularly urgent need to introduce the set-aside of arbitral awards in the local law.

- While there is no legislative will to introduce UNCITRAL Model Law, the courts of general jurisdiction shall be able to determine the violations of due process, to find correct applicable law and, if there is no law governing the contested relation, a court shall act in accordance with general legal principles.

\section{BIBLIOGRAPHY}

\section{Literature}

1. Civilprocesa likuma komentāri. I daļa [Commentaries on the Civil Procedure Law, Part I]. Chapters 1-28. Torgāns K. (scientific ed.), Tiesu namu aǵetūra, 2011.

2. Barnett P. Res Judicata, Estoppel, and Foreign Judgments. Oxford University Press, 2009, p. 8

3. Born G. International Commercial Arbitration, Vol. III, Wolters Kluwer, 2014.

4. Erk-Kubat N. Parallel Proceedings in International Arbitration: A Comparative European Perspective. Kluwer Law International, 2014, p. 234.

27 See in opposite Article 16(3) of the Model Law:

[..] If the arbitral tribunal rules as a preliminary question that it has jurisdiction, any party may request, within 30 days after having received notice of that ruling, the court specified in article 6 to decide the matter, which decision shall be subject to no appeal [..].

28 Article 5(5) of the Civil Procedure Law. 
5. Hanotiau B. Complex Arbitration: Multiparty, Multicontract, Multi-Issue and Class Actions. Kluwer Law International, 2006.

6. Krūmiņš T. Arbitration and Human Rights: Lack of Setting-Aside Proceedings as a Violation of the ECHR. PhD Thesis at the University of Copenhagen, Faculty of Law, 2019.

7. Rivkin D.V. Chapter 10. The Impact of Parallel and Successive Proceedings on the Enforcement of Arbitral Awards. In: Bernardo Cremades Sanz Pastor and Julian David Mathew Lew (eds.), Parallel State and Arbitral Procedures in International Arbitration, Dossiers of the ICC Institute of World Business Law, Vol. 3, Kluwer Law International; International Chamber of Commerce, 2005.

\section{Legislative acts}

1. United Nations Convention on the Recognition and Enforcement of Foreign Arbitral Awards. 330 UNTS 38, 1968.

2. European Convention on International Commercial Arbitration. 484 U.N.T.S. 364, 1961.

3. Civil Procedure Law. Available at: https://likumi.lv/ta/en/en/id/50500-civil-procedure-law [last viewed October 28, 2019].

4. Arbitration Law. Available at: https://likumi.lv/ta/en/en/id/269189-arbitration-law [last viewed October 28, 2019].

5. Law On Judicial Power. Available at: https://likumi.lv/ta/en/en/id/62847-on-judicial-power [last viewed October 28, 2019].

\section{Legal practice}

1. Judgment of the Constitutional Court of 28 November 2014 in the case No. 2014-09-01, \$ 15.4. Available at: http://www.satv.tiesa.gov.lv/web/viewer.html?file=/wp-content/ uploads/2014/03/2014-09-01_Spriedums_ENG.pdf\#search=2014-09-01 [last viewed May 2, 2019].

2. Judgment of the Constitutional Court of the Republic of Latvia of 17 January 2005 in the case No. 2004-10-01 § 9.1. Available at: http://www.satv.tiesa.gov.lv/web/viewer.html?file=/ wp-content/uploads/2004/05/2004-10-01_Spriedums_ENG.pdf\#search=2004-10-01 [last viewed October 28, 2019].

3. Judgment of Supreme Court of Latvia of 24 January 2013 in the civil case No. SKC-7/2013. Available at: http://www.at.gov.lv/downloadlawfile/3027 [last viewed October 28, 2019].

4. Judgment of Riga District Court of 1 November 2017 in the civil case No. C30748516. Available at: https://manas.tiesas.lv/eTiesasMvc/nolemumi/pdf/347096.pdf [last viewed October 21, 2019].

5. International Law Association Resolution No. 1/2006 "Recommendations on Lis Pendens and Res Judicata and Arbitration, 4-8 June 2006.

6. UNCITRAL Model Law on International Commercial Arbitration (1985), with amendments as adopted in 2006. Legislation based on the Model Law has been adopted in 80 States in a total of 111 jurisdictions. Available at: https://uncitral.un.org/en/texts/arbitration/ modellaw/commercial_arbitration/status [last viewed October 21, 2019].

7. The Rules of the Court of Arbitration of the Association of Commercial Banks of Latvia, 2017. Available at: http://www.fstiesa.lv/en/court_of_arbitration/ [last viewed October 28, 2019]. 